

RESEARCH ARTICLE

\title{
CHALLENGES TO IMPLEMENT PROPER ACCOUNTING PRACTICES IN MICRO AND SMALL SCALE ENTERPRISES (MSE), IN CASE OF WOLAITA SODO TOWN, ETHIOPIA.
}

\author{
Mr. Garedew Ganecho Gebremedihin.
}

Faculty of Business and Economics, Department of Accounting and Finance, Wolaita Sodo University, Ethiopia.

\section{Manuscript Info}

Manuscript History

Received: 06 January 2018

Final Accepted: 08 February 2019

Published: March 2019

Key words:-

Accounting practice, Challenges, Micro and Small scale.

\begin{abstract}
The importance of maintaining proper books of accounts and accurate accounting practices have been emphasize in ensuring proper financial management in SME. This study, examines challenges that affect the application of accounting practice of micro and small scale enterprises in Ethiopia, in the case of sodo town. Unsuccessfulness as well as loss of hope to operate on micro and small scale enterprises is common difficulties. To achieve the research objectives the researcher applied descriptive research design, primary data were collected by using Proportionate stratified sampling technique from samples of 209 owners. Chi-square test was used to examine the factors that affect the application of accounting practices. The results of the study concluded that respondents have understanding on contribution of accounting practice for growth of enterprises but they are not properly implementing, because of Lack of skills to handle asset and liability to prepare financial statements, distrustful attitude of owner, Cost of hiring qualified employees, finally fear taxation to disclose all information. Finally the researcher recommended that implementation of accounting practice by knowledgeable person provides true reflection of the enterprises financial performance that required for quality decision making towards success.
\end{abstract}

Copy Right, IJAR, 2019,. All rights reserved.

\section{Introduction:-}

Ethiopia is one of the countries that are working towards the achievement of Sustainable Development Goals. The first goal of sustainable development aim is to eliminate poverty and hunger by halving the population living on less than a dollar per day and the population suffering from hunger. Ethiopian government aims to create a very large number of job opportunities and ensure fair wealth distribution through, among other measures, by expanding small, medium and large industries. Micro and Small Enterprise Development Policy \& Strategy supports all aspects of urban development and housing through job creation and Ethiopia's transformation into an industrialized economy with middle income country status.

As Prasad (2001) argue, growing SMEs will also contribute to expanding the size of the directly productive sector in the economy; generating tax revenue for the government; and, all in all, facilitating poverty reduction through fiscal transfers and income from employment and firm ownership. In recognition of the major role MSEs play in the country's economic and social development, Government of Ethiopia has given much greater attention to MSE

Corresponding Author:-Garedew Ganecho Gebremedihin.

Address:-Faculty of Business and Economics Department of Accounting and Finance, Wolaita Sodo 
development. As result of government attention to MSEs in Ethiopia the numbers, and its contribution to whole economy is visible, while is hard for the SMEs to access finances from the financial institutions because of proper financial records and standardized financial reports as a requirement by financial institutions (William, 2008). Unfortunately most SMEs in Ethiopia managed by owner, lack accounting qualification and sometimes they have less motivations for financial accounting information because of their personal involvement in the day-to-day operations. As the result may whole true especially evidence not included for finance.

To enable seekers of finance and providers of finance makes an informed economic decision; there is the need to have reliable accounting information which has been generated through sufficient accounting system. That requires proper books of account are kept. An insufficient accounting system is a primary factor in small business failures. Quality of SME records keeping attract investors to invest and for financial institution to provide finance, Tagoe (2001). Most providers of finance assure themselves with financial accounting information generated from an adequate accounting system in order to reduce risk.

Research conducted in this area shows, by (Michael,2009), Zahra A. (2011), indicate that SMEs have faced challenges like; lack of access to credit, cheap imports, insecurity and debt collection, lack of good management, no support from banks and financial institutions, inadequate economic sphere, and insufficient governmental policies. In turn (Oprean, 2001), Ismail and King (2007), and Mahon (1999) concluded that accounting information must be accurate and reliable, homogeneous and verifiable, useful, and timely at the same time. Also, at economic entities in general, and those in the trade, in particular, accounting information must be presented in accordance with their legal and economic basis, applying the accounting rules to be performed with sincerity, and the information to be provided on a regular basis, so that they can be used in the sound decision-making process, by persons who possess this quality. The studies of Dyt and Halabi (2007) and Zhour (2010) concluded that the main problem of business owner and managers of micro enterprises is mostly in their inability to keep sufficient records to aid them in their decision-making. Results of their studies show that majority of micro businesses rely more heavily on manual methods /they hold their business traditionally/, while small businesses are more likely to use computerized systems. Other researcher like Amoako (2013) stated that SMEs do not maintain proper books of accounts because owners do not appreciate the need to keep accounting records, lack accounting knowledge and find the cost of hiring professionals too expensive. As per (pasha, 2017) SMEs in Ethiopia often face problems with regard to recording their daily transactions. This is due to the fact that most of the SMEs operators do not know how to maintain such records in a simple and easy manner.

As a result, many operators find it very difficult to give information on their income and expenditure and ultimately do not know whether they have lost or profited from their business activities. From those reasons lack preparation of proper bookkeeping and basic accounting procedures are considerable. In this town most enterprise operators haven't prior experience in basic accounting and business management and thus they were not able to successfully manage their businesses. As the result enterprises failed and loss of hope, even extreme anxiety, to operate micro and small scale enterprises.

The main objective of this study is to assessing the accounting Practices of Micro and Small Enterprises. Specificobjectives are:-

To determine the extent to which recordkeeping and basic accounting procedures have been implemented in MSEs, To find out challenges that faced by the MSE entrepreneurs in recordkeeping. Finally, to identify how MSEs know their profit and loss without proper accounting practice. The study is to give overriding importance for all MSE to become aware for various accounting records and practices with great care and accuracy, also give unmistakable significance for MSE, to evaluate their accounting operations with theoretical accounting principles.

\section{Hypothesis}

\section{Hypothesis-1}

Ho: Lack of skills to handle asset and liability is not reason to implement proper accounting practices and principles by MSE in soddo town.

H1: Lack of skills to handle asset and liability is considered as reason to implement proper accounting practices and principles by MSE in soddo town. 


\section{Hypothesis-2}

Ho: - Lack of accounting skill how to prepare financial statements not factor to implement proper accounting practices and principles by MSE in soddo town.

H1: Lack of accounting skill how to prepare financial statements is one factor to implement proper accounting practices and principles by MSE in soddo town.

\section{Hypothesis-3}

Ho: Distrustful attitude of owner for book keeping is not considered as factor to implement proper accounting practices and principles by MSE in soddo town.

H1: Distrustful attitude of owner for book keeping is critical factor to implement proper accounting practices and principles by MSE in soddo town.

\section{Hypothesis-4}

Ho: Cost of hiring qualified employees from market is not a factor to implement proper accounting practices and principles by MSE in soddo town.

H1: Cost of hiring qualified employees from market is a factor to implement proper accounting practices and principles by MSE in soddo town.

\section{Hypothesis-5}

Ho: Fear of disclose all information by considering taxation is not a factor to implement proper accounting practices and principles by MSE in soddo town.

H1: Fear of disclose all information by considering taxation is a one factor to implement proper accounting practices and principles by MSE in soddo town.

\section{Literatures Review \\ Definitions of MSEs}

There is no universally accepted definition of SMEs because in each economic system every country has its own classification according to their industrial regulation. Small scale enterprises has been defined variously by many individuals and institution using various criteria's such as numbers of employees, volume of sales, value of assets, or the volume of deposit in banks (Ademola et al 2012). The Source of information Cited by (Tadesse, 2010), Micro and small enterprises are defined in several countries within their different reasons. Thus, definition depends on the government policies of the country.

\begin{tabular}{|l|l|l|}
\hline Country & Category of industry & Criteria \\
\hline USA & Very small enterprise & $10-499$ employees \\
\hline France & MSE & $<500$ employees \\
\hline \multirow{3}{*}{ Ghana } & Micro enterprise & $1-4$ employees \\
\cline { 2 - 3 } & Small enterprise & $5-29$ employees \\
\cline { 2 - 3 } & Medium enterprise & $30-140$ employees \\
\hline \multirow{2}{*}{ Ethiopia } & Micro enterprise (ME) & Capital $<$ Br 20,000 \\
\cline { 2 - 3 } & Small and medium enterprise & Capital $\mathrm{Br} 20,000-50,000$ \\
\hline
\end{tabular}

\section{Accounting Practices and Book-Keeping in SMEs}

Many authors have defined the term "Accounting" in different ways. There is difference of opinion among the authors as to its precise definition as the term accounting is so broad that it is difficult to give precise definitions. Many authors one agreed that, Accounting is a systematic process of identifying, recording, measuring, classifying, verifying, summarizing, analyzing and interpreting and communicating financial information. It discloses profit or loss for a given period, and the value and nature of a firm's assets, liabilities and owners' equity, (Dictionary, 2018). Cited by (Adjei Luther Ntim, 2014), Accounting have a dominant in any business. Accounting is basically defined as the process of recording economic information in a significant manner in order to measure the performance of a firm. Basic accounting is needed to "keep the score" so that the entrepreneur knows what is happening in the business, how much has been sold, what the costs are, what activities are profitable, and so on. Accounting practices consist of the methods and records established by management to identify, assemble, analyze, classify, record and report a company's transactions and to provide assurance that the objectives of internal control are being met. This is sometimes called the accounting system. It analyze, record and measures business transactions to ascertain the 
performance of an entity. A good accounting system is not only judged by how well records are kept but by how well is able to meet the information needs of both internal and external decision-makers. (Maseko, D. and Manyani, O. 2011), suggested that for a small or micro business, accounting practices will involve the maintenance of adequate Cash Book (if possible with analysis), Bank Accounts (with policies on deposits and withdrawals), Petty Cash system, irregular or regular preparation of Bank Reconciliation statement, Credit Policies with creditors for Purchases and with customers on Sales, Stock-keeping policy, Fixed Asset register and Budgeting for the entire business. The accounting transactions of an enterprise need to be recorded in the accounting books. The process of recording and maintaining these books is known as book-keeping. Efficient financial mangers reside on the past and present in order to predict the future and for proper evaluation and comparison of financial activities. To achieve this aim, proper book-keeping remains integral. UNCTAD (2000), observed the need for promoting transparency with adequate records-keeping early on in the business development phase of SMEs as paramount. Some form of recording will be essential to all business for the day-to-day management of their operations and the fulfillment of unavoidable governmental obligations (e.g. taxation). It is well known that inadequate record keeping is frequently associated with failures in small businesses even if it is not actually the direct cause of failure. For record keeping purposes the enterprise can use different methods. A report submitted by the European Commission Enterprise and Industry Directorate-General on the accounting systems for small enterprises (2008), suggested the following as the main books to be kept by an SME owner: Purchase day book, Sales day book, Cash book, Petty cash book, Expenditure book, Payroll records, Assets register etc.

\section{Important of Good record keeping of MSE}

Appropriate bookkeeping and accounting procedures have provided some importance of good records keeping including the fact; unless your business is accounting or bookkeeping, keeping financial records is probably not what you do best. Most likely, you would rather spend your time selling your product or service. However, if you are going to run a successful business, accurate and timely financial information is a must. Furthermore, as per Longneck and Moore; (1988), Smith et al; (1989) evaluating the financial cost is part of every business decision made. Without accurate records and financial information, it may be hard to know the financial impact of a given course of action. They go on to say that, outside investor, creditors and a bankers regularly want to see financial statements for the most current and prior years, as well as your projected statements showing the impact of the requested loan and for potential investment.

\section{Research Methodology:- \\ Research Design}

The study applied descriptive research design. This design seeks to describe subjects, often by creating a profile of a group of problems, people, or events, through the collection of data and tabulation of the frequencies on research variables (Cooper \& Schindler, 2006). A descriptive research defines questions, people surveyed, and the method of analysis prior to beginning data collection. Therefore, this approach is appropriate for this study, since the researcher intended to collect detailed information through descriptions and is useful for identifying variables and notional constructs.

\section{Target population}

The target population containing of 1051 registered SMEs Wolaita Sodo towns. These were selected depending on the type of business that is wholesale shop, Retail shops and small scale producers with identification numbers.

\section{Sample size and Sampling techniques}

According to trade and industry bureau of Sodo town, 1051 total populations participated in service, manufacturing, construction sectors, Urban agricultural and Trade sector. To determine sample size Yamane (1967) provides a simplified formula to calculate sample sizes. This formula assumed a 95\% confidence level and margin of error (e) 0.05. The sample size of the study was determined using the formula: $\mathrm{n}=\frac{N}{1+N(e) 2}$

Where ' $\mathrm{n}$ ' is the sample size, ' $\mathrm{N}$ ' is the population size, and ' $\mathrm{e}$ ' is the level of precision $\mathrm{N}=1051$ which is the total population and significant level is $(\mathrm{e})=0.05$. Then, the sample was, $\frac{1051}{1+1051(0.05) 2}=$ 290; ample that expecting can represent the total population.

Table 2:-Distribution of SMEs by sector

\begin{tabular}{|l|l|l|l|}
\hline Sectors & Total & Population ratio & Sample size \\
\hline
\end{tabular}




\begin{tabular}{|l|l|l|l|}
\hline & population & & \\
\hline Service & 238 & $290(238 / 1051)$ & 66 \\
\hline Manufacturing & 133 & $290(133 / 1051)$ & 37 \\
\hline Construction & 146 & $290(146 / 1051)$ & 40 \\
\hline Urban agricultural sector & 82 & $290(82 / 1051)$ & 23 \\
\hline Trade sector & 452 & $290(452 / 1051)$ & 124 \\
\hline Total & 1051 & $290(1051 / 1051)$ & 290 \\
\hline
\end{tabular}

Source: secondary data 2011

The sampling technique selected for this study was proportionate stratified sampling technique. Proportionate stratified sampling is a probability sampling technique wherein the researcher divides the entire population into different subgroups or strata, then randomly selects the final subjects proportionally from the different strata (Steven Nickolas, 2017). This technique is employed to use the same sampling fraction for each stratum regardless of the differences in population size of the strata. The stratified sampling used by the researcher divided the target population in to four-sub city's that is individually more homogeneous than the total population or into strata and select item from each stratum to constitute sample. The researcher used simple random sampling to select the sample from each stratum.

\section{Data Source and collection method}

The study was carried out by gathering data from primary sources; self-administered interviews and questionnaire were employed as the major techniques for primary data collection. In addition, secondary data was obtained from books, magazines, journals, and even from the internet in order to achieve the research objectives.

\section{Data presentation and analysis}

According to Kasomo (2006) defines data analysis as the process of bringing order to data and manipulating it. It involves organizing data into patterns, categories and basic descriptive units. The researcher organized the data to ensure that raw data was sorted and coded. Data analysis was done with guidance of a statistician using SPSS computer software. Information from the analyzed data was presented using percentages and frequency distribution tables.

\section{Data Analysis and Discussions:- \\ Profile of Respondents and Surveyed Firms}

According to the survey result from table 4.1, analyzed that the types of enterprise which operated on different sector, 66(22.8\%) of the respondents of participated on service sectors, 37(12.8\%) Manufacturing on sector, $44(15.2 \%)$ of the construction, $19(6.6 \%)$ on Urban agricultural, $124(42.8 \%)$ percent of the trade sector. This indicates that majority enterprise operated in soddo town is on trade sector.

Table 4.1:-Demographic character of the respondent

\begin{tabular}{|c|c|c|c|c|c|}
\hline Type & Freq. & $\%$ & Education & Freq. & $\%$ \\
\hline Service & 66 & 22.8 & Informal & 46 & 15.9 \\
\hline Manufacturing & 37 & 12.8 & 1 to 8 & 71 & 24.5 \\
\hline Construction & 44 & 15.2 & $8-12$ & 58 & 20.0 \\
\hline Urban agricultural & 19 & 6.6 & Below Degree & 93 & 32.1 \\
\hline Trade & 124 & 42.8 & Degree & 22 & 7.6 \\
\hline Total & 290 & 100 & Total & 290 & 100 \\
\hline Age & Freo & or & Gendir & Frea & of \\
\hline 18 up to 29 & 180 & 62.1 & Male & 167 & 57.6 \\
\hline 30 up to 45 & 83 & 28.6 & Female & 123 & 42.4 \\
\hline Above 45 & 27 & 9.3 & Total & 290 & 100. \\
\hline Total & 290 & 100.0 & \multicolumn{3}{|c|}{ Source: own survey 2019} \\
\hline
\end{tabular}

When we come on gender participation, on micro and small scale enterprise 167(57.6) of the respondents are male and $123(42.4 \%)$ of the respondents are female. The Age of the respondent shows that 18 up to $29,30,180(62.1 \%)$, up to 45 , above $45,83(28.6 \%)$ and Age above 45, 27(9.3\%). This indicates that majority of MSE, owners or 
Managers are male and on young stage. When the education background analyzed, informal education occupied $46(15.9 \%)$, 1up to $8^{\text {th }}$ grade $71(24.5 \%), 8^{\text {th }}$ grade up to $12^{\text {th }}$ grade $58(20 \%$, below degree, means diploma and any certificated 93(23.1\%), and Degree 22(7.6\%). As the majority of Micro and small scale enterprise managers/ owners have an education level below degree (TVET-diploma level).

\section{Importance of Accounting Records Keeping}

According to Padachi, K. (2012), the need for businesses to keep proper financial records and argued that proper system of financial records provide how well the business is performing and what decisions are necessary to be made in order to keep the business in the market. Abdul-Rahamon, O. A., \& Adejare, A. T. (2014), Mbroh, J.K., \& Attom, B.E. (2012), noted that, accounting records improves the performance of a business and as reference, there is a strong positive relationship between accounting records keeping and performance of small scale enterprises. Most businesses are concerned in measuring their profitability and to determine the profit, they should adopt suitable accounting bases, concepts, principles and standards to ensure the reliability of its measurement. Accounting records keeping is essential for decision making which invariably affects the performance of enterprises. The financial records enable owners/ managers to determine whether or not the business is operating at a profit and whether the business was able to meet its obligations pay back.

Table 4.2:-Opinion of respondent on important of Accounting practice for growth of Enterprise.

\begin{tabular}{|l|l|l|l|l|}
\hline \multicolumn{2}{|c|}{} & Freq. & Percentage & Valid \% \\
\hline \multirow{5}{*}{} & Strongly disagree & 29 & 10.0 & 10.0 \\
\cline { 2 - 5 } & Disagree & 29 & 10.0 & 10.0 \\
\cline { 2 - 5 } & Neutral & 17 & 5.9 & 5.9 \\
\cline { 2 - 5 } & Agree & 139 & 47.9 & 47.9 \\
\cline { 2 - 5 } & Strongly Agree & 76 & 26.2 & 26.2 \\
\cline { 2 - 5 } & Total & 290 & 100.0 & 100.0 \\
\hline
\end{tabular}

Source, own survey 2019

According to the survey made by the researcher, on table 4.2 indicates that $47.9 \%$ respondent agreed on accounting records have positive contribution for growth of their enterprise and $26.2 \%$ of respondent strongly agreed that accounting records have contribution for their business growth. From survey evidence the researcher conclude, that micro and small scale enterprise of the managers/ owners in soddo town have well understanding on contribution of accounting practices for success of MSE.

\section{Accounting practices}

Table 4.3, Represents, Frequency, mean and standard deviations for applicable accounting practices; first item states that all assets and liabilities of the enterprise are recorded when

Table 4.3:-Practical accounting practices

\begin{tabular}{|c|c|c|c|c|c|c|c|c|c|c|c|c|}
\hline \multirow[t]{2}{*}{ Items } & \multicolumn{2}{|c|}{$\begin{array}{r}\text { Strongly } \\
\text { Disagreed }\end{array}$} & \multicolumn{2}{|c|}{ 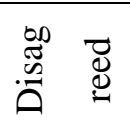 } & \multicolumn{2}{|c|}{ 竞 } & \multicolumn{2}{|c|}{  } & \multicolumn{2}{|c|}{$\begin{array}{l}\text { Strongly } \\
\text { Agreed }\end{array}$} & \multirow[b]{2}{*}{ 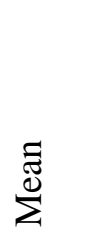 } & \multirow[t]{2}{*}{$\begin{array}{l}\text { Std. } \\
\text { Deviation }\end{array}$} \\
\hline & $\stackrel{0}{0}$ & $0^{\circ}$ & $\dot{\bar{g}}$ & $0^{\circ}$ & $\underset{\dot{d}}{\dot{d}}$ & $b^{\circ}$ & $\dot{\bar{g}}$ & $b^{\circ}$ & 过 & $\%$ & & \\
\hline $\begin{array}{l}\text { Do you record all Asset and } \\
\text { liability of the Enterprise } \\
\text { when events are occurred? }\end{array}$ &  & छें & సิ & $\stackrel{n}{8}$ & $\tilde{\boldsymbol{N}}$ & $\stackrel{b}{r}$ & $\stackrel{\infty}{=}$ & ชู & $\stackrel{2}{=}$ & $\stackrel{1}{+}$ & 2.30 & 5.79 \\
\hline $\begin{array}{l}\text { Do keep all receipts and } \\
\text { invoices of transactions in an } \\
\text { organized manner? }\end{array}$ & $\stackrel{\infty}{ \pm}$ & $\bar{n}$ & $\stackrel{\varepsilon}{=}$ & సై & $\stackrel{\infty}{\sim}$ & ชู & 윽 & $\ddot{r}$ & $a$ & $\overrightarrow{\dot{m}}$ & 1.71 & .95 \\
\hline $\begin{array}{l}\text { Does your enterprise record } \\
\text { all the money withdrawn for } \\
\text { personal use? }\end{array}$ & $\Xi$ & กั? & ભొ & $\stackrel{\infty}{\dot{\nabla}}$ & $\stackrel{\bullet}{0}$ & n? & こ & के & 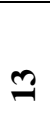 & $\stackrel{10}{7}$ & 1.91 & 1.04 \\
\hline
\end{tabular}




\begin{tabular}{|c|c|c|c|c|c|c|c|c|c|c|c|c|}
\hline $\begin{array}{l}\text { Does your enterprise separate } \\
\text { your personal resources from } \\
\text { business finances? }\end{array}$ & กี & $\begin{array}{l}10 \\
18\end{array}$ & $\Xi$ & mo & $\mathfrak{I}$ & $\overrightarrow{+}$ & $\stackrel{\infty}{\sim}$ & ชู & 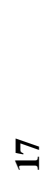 & in & 1.89 & 1.12 \\
\hline $\begin{array}{l}\text { Does your enterprise give } \\
\text { customers receipt and stay } \\
\text { with a copy? }\end{array}$ & $\stackrel{\stackrel{\Im}{二}}{\sim}$ & $\overrightarrow{7}$ & $\ddot{m}$ & in & $m$ & $\stackrel{10}{+}$ & in & F & 윽 & $\dot{\vec{r}}$ & 2.08 & 5.78 \\
\hline $\begin{array}{l}\text { Does your enterprise adjust } \\
\text { accounts when debtors settle } \\
\text { their debts? }\end{array}$ & 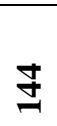 & $\hat{\theta}$ & $\stackrel{ }{\theta}$ & 官 & $=$ & $\ddot{\infty}$ & $\ddot{r}$ & $\stackrel{n}{*}$ & 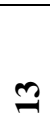 & $\stackrel{n}{+}$ & 1.77 & 1.03 \\
\hline $\begin{array}{l}\text { Does your enterprise check } \\
\text { whether debits and credits } \\
\text { balance of all enterprise } \\
\text { financial information? }\end{array}$ & సิ & $\stackrel{n}{8}$ & $\ddot{\beth}$ & $\stackrel{\vec{v}}{\stackrel{\sim}{*}}$ & \pm & $\stackrel{\infty}{+}$ & $\ddot{r}$ & $\dot{\nabla}$ & $=$ & $\ddot{m}$ & 1.81 & .99 \\
\hline
\end{tabular}

Source: own survey 2019

events are occurred, out of 290 responded , $81.4 \%$ (Disagree $=44.5 \%$ \& strongly disagree $=36.9 \%$ ) on recording asset and liability when events are occurred, with average score of 2.3 and standard deviation of 5.8, keeping receipts and invoices of transactions in an organized manner is essential function to watch apt verifications but 148 (51\%) strongly disagreed and $105(36.2 \%)$ disagreed with mean score of 1.71 and standard deviation of 0.95 , the recoding habits of enterprise when the owners withdrawn money for personal use was strongly disagree by 114 (39.3\%) and disagreed by $130(44.8 \%)$ of the respondent with mean of 1.91 and standard deviation of 1.04 . Result indicates of study point out that the business entity principle was violated by the enterprise, as response that $132(45.5 \%)$ of the strongly disagree and 111(38.3) disagreed are with average score of 1.89 and standard deviation of 1.12 , customers receipt is used as source document for any business but $128(44.1 \%)$ of the respondent strongly disagree and 133(45.9) disagreed to staying customer receipts with mean score of 2.08 and standard deviation of 5.78, to get updated information adjustment debtors account is important accounting activity while 144(48.7\%) of the strongly disagree and 109(37.9) disagreed with mean score of 1.91 and standard deviation of 1.04 and checking all debits and credits balance of all enterprise financial information used to understand the financial position of the enterprise, but from the respondents 129(44.5\%) of the strongly disagree and 123(42.4) disagreed with mean score of 1.81 and standard deviation of 0.99 . The standard deviations could give an approaching as to the consistency of the responses among all the respondents. Higher std. deviation shows that less consistency in the responses; meaning the responses are quite diverse opinion; and a small standard deviation indicates more uniformity in the responses; meaning the responses of the respondents have similar opinion. As the researcher observes that, less consistent scoring was found from the respondent's response on recording of all Assets and liability of the Enterprise when events are occurred with somewhat larger standard deviation. This might be related to personal opinion or experiences of the respondents on system recording events. The result of the study shows that majority Micro and small enterprise in Soddo town not properly implement accounting principles and practices because of several reasons.

\section{Factors that Affect to implement proper accounting records}

Implementation of proper Accounting practice by MSEs is subject to different set of consistent factors. To examine the factors that determine the accounting practice of MSEs, Chi-square testhas been used to examine the relation of factors (dependent variables) with application of accounting practice (Independent variable).

Table 4.4:- Factors affecting properly implementing accounting practices

\begin{tabular}{|l|l|l|l|}
\hline \multicolumn{1}{|c|}{ Factors } & $\begin{array}{l}\text { Chi-square } \\
\text { value }\end{array}$ & DF & P-value \\
\hline $\begin{array}{l}\text { Is lack of skills to handle asset and liability of the enterprise is affect } \\
\text { the performance of the business? }\end{array}$ & $22.695^{\text {a }}$ & 12 & .030 \\
\hline $\begin{array}{l}\text { Is lack of accounting skill how to prepare financial statements having } \\
\text { its own effect on performance of the Micro and Small Scale } \\
\text { Enterprises? }\end{array}$ & $24.875^{\text {a }}$ & 12 & .015 \\
\hline Is the distrustful Attitude of Business owner for have its own negative & $8.140^{\text {a }}$ & 3 & .043 \\
\hline
\end{tabular}




\begin{tabular}{|l|l|l|l|}
\hline effect to keep business records and to prepare financial statements? & & & \\
\hline $\begin{array}{l}\text { Cost hiring qualified employees from market demoralize the owner and } \\
\text { have disadvantage on preparation of financial statement of MSE- } \\
\text { Enterprise in Ethiopia. }\end{array}$ & $25.598^{\mathrm{a}}$ & 12 & .012 \\
\hline $\begin{array}{l}\text { Fear of disclose all information by considering taxation to prepare } \\
\text { financial statements of MSE-enterprise? }\end{array}$ & $22.654^{\mathrm{a}}$ & 12 & .031 \\
\hline
\end{tabular}

Source: own survey 2019

As the researcher tested Null hypothesis, that the properly implementation of accounting practices according with accounting principles byenterprises (independent variables) in Soddo town is not affected by different factors (luck of skills to handle asset and liability, lack of accounting skill how to prepare FS, Distrustful Attitude of Business owner, Cost hiring qualified, Fear of taxation) at 5\% level is significant by using Chi-square test. Results of the test show that the application of accounting practice by MSE- affected by different dependent factors with the level of the respondents response, p-value of the all factors is less than 0.05 , as the result we reject all null hypothesis (H0), hence we conclude that application of accounting practices and principles by MSE in Ethiopian- particularly in Soddo town was affected by above anticipated factors.

\section{Conclusion and recommendation:- Conclusion}

In this study the researcher interested to examine how well the accounting practices are implemented also what are the factors that undermine the enterprise effort. Almost all respondent are informed on contribution of accounting practice for growth of their enterprises. In practically on the ground they are apply accounting practices and principles in appropriate way because of Lack of skills to handle asset and liability, inability how to prepare financial, Distrustful attitude of owner /manager, Cost of hiring qualified employees, finally fear to disclose all information by in view of taxation to government.

\section{Recommendation:-}

To protect micro and small scale enterprises from unsuccessfulness; the following recommendation should be implemented by the concerned bodies: To facilitate the growth of their business the researcher recommended that MSE- should implemente in full accounting/ bookkeeping/ practices. If they implement accounting practice according to accounting principles it show the true reflection of the business' financial performance that required for quality decision making towards business success. Application of accounting practice without education back ground is extremely complex activity hence if they recruit educated employees to handle financial related activities the business frailer as well as taxation issue will be solved.

\section{Reference:-}

1. Abdul-Rahamon, O. A., \& Adejare, A. T. (2014). The Analysis of the impact of Accounting Records Keeping on the Performance of the Small Scale Enterprises. International Journal of Academic Research in Business and Social Sciences, 4(1), ISSN: 2222-6990.

2. Adjei Luther Ntim, O. E. (2014). Accounting practices and control systems of small and medium size entities: A case study of Techiman municipality. Journal of Finance and Accounting , 4.

3. Ajao OS, Oyeyemi OG, Moses OI (2016).Bookkeeping and sustainability of small scale businesses in Nigeria: An assessment of Agbara Local Government Area, Ogun State. Unique Journal of Business Management Research 3: 11-21.

4. Amoako, G.K. (2013). Accounting Practices of SMEs: A Case Study of Kumasi Metropolis in Ghana. International Journal of Business and Management, 8 (24). Pp. 73-83.

5. Cooper, D.R. \& Schindler, P.S. (2006). Business Research Methods. McGraw-Hill Irwin, Boston.

6. Dyt, R. and Halabi, A. K. (2007).Empirical evidence examining the accounting information systems and accounting reports of small and micro business in Australia, Small Enterprise Research, 15 (2), pp. 1-9.

7. Esubalew, A. A. (2017). Micro, Small and Medium Enterprises(MSMEs)Development Strategies in Ethiopia. International Journal of Commerce, Business and Management.

8. Gfdre G. o. (2011). MSEs Development, support scheme, and implementation strategies. Addis Ababa, Ethiopia. 
9. Independent Evaluation Group (2013), "Approach Paper Evaluation of the World Bank Group's Targeted Support for Small and Medium Enterprises," IEG World Bank, Washington DC.

10. Ismail, N. A. and King, M. (2007), Factors influencing the alignment of accounting information systems in small and medium sized Malaysian manufacturing firms, Journal of Information Systems and Small Business, 1,(1-2), pp. 1-20.

11. Galloway, A. (1997). Questionnaire Design \& Analysis. Available at: http://www.tardis.ed.ac.uk/ kate/qmoweb/qcont.htm [Accessed 18 May 2011]

12. GFDRE, G. o. (2011). MSEs Development, support scheme, and implementation strategies. Addis Ababa, Ethiopia

13. Kasomo, (2006): Research methods in humanities and education. Njoro Egerton university press.

14. Mahon, R.G.P. (1999). Modeling the Extent of Financial Reporting practices amongst Australian Manufacturing SMEs, Small Business Economics, 13 (2), pp.81-96.

15. Maseko, D. and Manyani, O. (2011), Accounting practices of SMEs in Zimbabwe: an investigative study of record keeping for performance measurement: Journal of accounting and taxation vol. 3(8), pp. 171181, December 2011.

16. Mbroh, J.K., \& Attom, B.E. (2012). "Accounting and Control Systems Practiced By Small and Micro Enterprise Owners within the Cape Coast Metropolitan Area of Ghana". Asian Journal of Business and Management Sciences, 1(9), 28-47

17. Michael B., Makarius. M.and Samuel M. (2009) Management of business challenges among small and micro enterprises in Nairobi-Kenya, KCA journal of business management: vol. 2, issue 1

18. M. o. (2016). Public Relations and Developmental Communication Secretariat of Micro and Small Enterprise Development Policy \& Strategy. Addis Ababa: GoE of Ethiopia.

19. Padachi, K. (2012). "Why SMEs Ignore Formal Accounting Systems? -Entity Concept Explanation" International Conference on Applied and Management Sciences (IAMS'2012) June 16-17, Bangkok.

20. Pasha, A. D. (2017). A Study on Accounting Practice and Financial Reporting in SMEs (In Case of Arba Minch Town, Snnpr, Ethiopia) . iiste, 2.

21. Pinson L (2007) keeping the books: basic record-keeping and accounting for the successful small business. United States of America: Kaplan Publishing.

22. Prasad, S. B., 2001. Globalization of Smaller Firms: Field Notes on Processes. Small Business Economics, 13:1-7.

23. Tadesse, B. (2010). The Role of Micro and Small Enterprises in Employment Creation and Income Generation ; A Survey Study of Mekelle City, Tigray Region, Ethiopia . 18.

24. Wichmann, H. (1983). Accounting and Marketing-Key Small Business Problems, American Journal of Small Business, 7(4), pp. 19-26.

25. Yamane, T. (1967), Statistics an introductory analysis. New York: Harper and Row

26. Zahra A. (2011), an empirical study on the causes of business failure in Iranian context, of Business Management Vol. 5(17).

African Journal 